\title{
Specify Other ERBB2 Non-Exon 20 Mutation
}

National Cancer Institute

\section{Source}

National Cancer Institute. Specify Other ERBB2 Non-Exon 20 Mutation. NCI Thesaurus.

Code C158891.

A request to enter the specific EGFR non-exon 20 mutation that was identified in the study but is not present in the form. 